Business Ethics and Leadership, Volume 3, Issue 4, 2019

ISSN (online) - 2520-6311; ISSN (print) - 2520-6761

\title{
Legal Aspects of Ethical Decision-Making in the Event of Sexual Harassment and Discrimination in the Workplace
}

http://doi.org/10.21272/bel.3(4).34-42.2019

Babu George, ORCID: https://orcid.org/0000-0002-2791-828X

$\mathrm{PhD}$, Associate Professor, College of Business, Fort Hays State University, USA

\begin{abstract}
Sexual harassment-related complaints in the workplaces have increased multifold in the recent past. It is unclear whether this is because of more frequent harassment incidents because victims feel more emboldened to report, or only because more media reports happen on these complaints these days. Regardless, employers have improved both preventive and recovery mechanisms in order to minimize the incidents, or if they happen, support the victims in the best possible manner and also to protect themselves from adverse judicial scrutiny. While courts do not necessarily consider the job related and psychological consequences of harassment cases, organizations also need to worry about these - even as they build lawsuitproof systems. In this paper, we discuss five historically important US Supreme Court lawsuits that would later have major consequences for how sexual harassment complaints are dealt within our contemporary workplaces. The five pioneering cases that would be discussed are Meritor v. Vinson; Faragher v. City of Boca Raton; Burlington Industries v. Ellerth; Gebser et al. v. Lago Vista Independent School District; and, Davis v. Monroe County Board of Education. The paper specifically elaborates on the implications of the court decisions upon these cases for subordinate-supervisor and student-teacher relationships in the US universities. Most harassment cases in the university contexts are not between employees but between employees/faculty and customers/students and this makes straightforward interpretation of court rulings difficult. The resultant ambiguity, along with the interest of universities to protect their reputations by suppressing incidents, make pursuing harassment investigations difficult. While these cases did not succeed in providing a saturated sample for generating a cohesive or comprehensive set of guidelines, they nevertheless guided future court judgements and also organizational policies with respect to managing sexual harassment. In the conclusion section of this paper, the author offers a glimpse into newer forms of sexual harassment, particularly those mediated by social media technologies, and offers ways for organizations to deal with them.
\end{abstract}

Keywords: business ethics, discrimination, sexual harassment, lawsuits, Civil Rights Act of 1964, Universities, Supreme Court, United States.

JEL Classification: I3, K4, Y8.

Cite as: George, B. (2019). Legal Aspects of Ethical Decision-Making in the Event of Sexual Harassment and Discrimination in the Workplace. Business Ethics and Leadership, 3(4), 34-42. http://doi.org/10.21272/bel.3(4).34-42.2019.

(C) The Author, 2019. This article is published with open access at Sumy State University.

\section{Introduction}

Beginning late 1980s, there is an explosion of scholarly interest in workplace sexual harassment cases (Fitzgerald \& Cortina, 2018). This interest coincided with some of the landmark Supreme Court decisions regarding workplace discrimination and sexual harassment. Previous to this, scholars did examine it from the general frameworks of workplace adaptability and organizational climate issues rather than in the light of empirical data provided by court judgments (Cohen, 1987). Sexual harassment is still a bourgeoning problem in the workplaces around the world and that the legal approaches to resolve a greater cultural problem like this have not met with easy solutions.

Figure 1 below offers a glimpse into whether harassment is prohibited in different countries in the world: 


\section{Is sexual harassment explicitly prohibited in the workplace?}

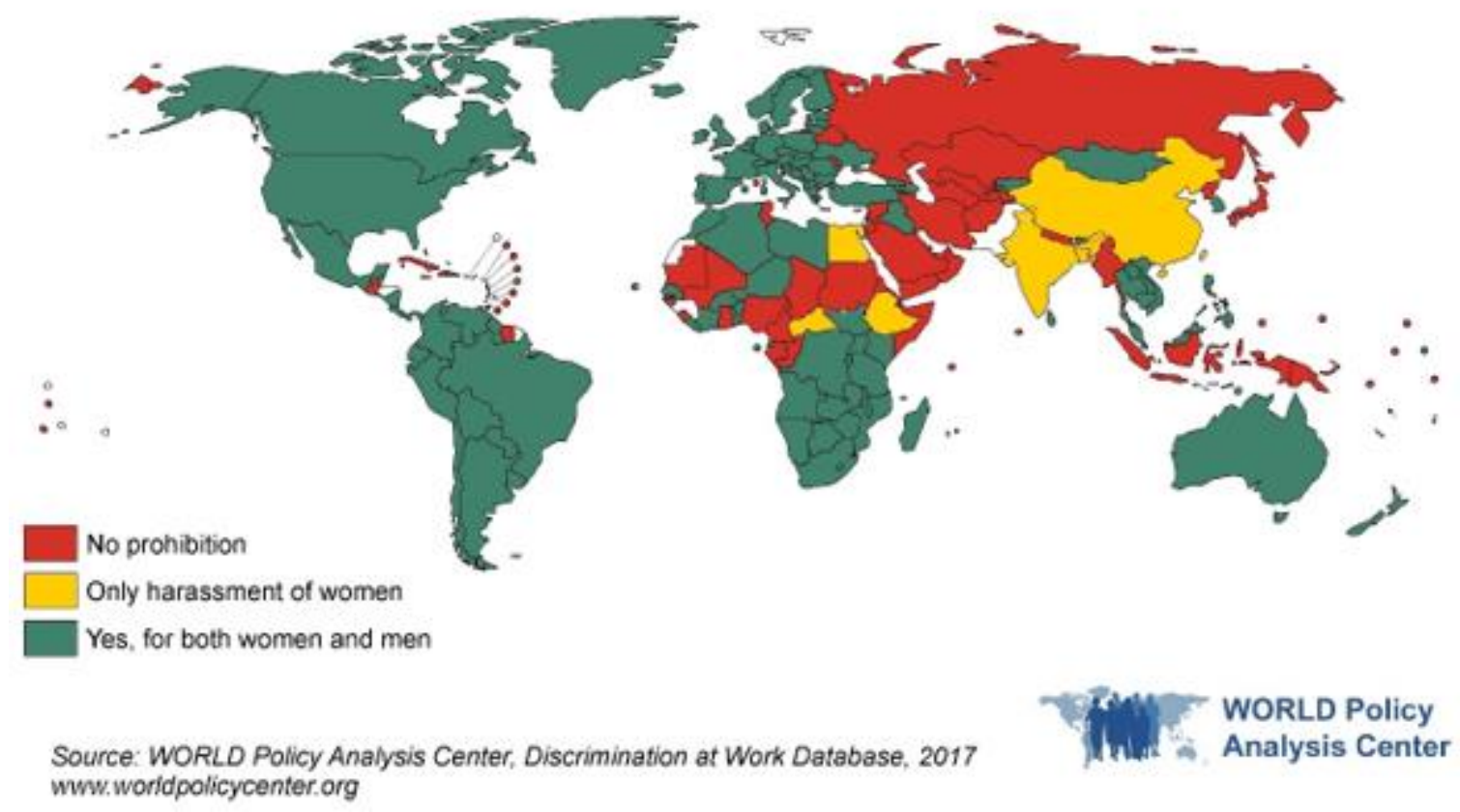

Figure 1. Country by country differences on how sexual harassment is viewed

Source: World Policy Analysis Center

According to Rape, Abuse \& Incest National Network (RAINN), sexual violence on US school and campuses is persistently high. In all college and professional students, $8.8 \%$ of women and $2.2 \%$ of men suffer from rape or sexual assault, either through coercion or sexual incapacitation. Among undergraduates, 23.1 percent of women experience violence and/or sexual assault through physical force. Since entering college, $4.2 \%$ of students have had been victims of stalking. RAINN also estimates that the assault rate is $21 \%$ among the TGQN (transgender, genderqueer, nonconforming) college students. Despite these, only around $20 \%$ of the female student victims report the incidents to police. These findings come primarily from the US National Crime Victimization Survey (NCVS).

The five pioneering cases that would be discussed in this essay are Meritor v. Vinson; Faragher v. City of Boca Raton; Burlington Industries v. Ellerth; Gebser et al. v. Lago Vista Independent School District; and, Davis v. Monroe County Board of Education. While these five cases are by no means capable of providing a comprehensive understanding of the sexual harassment law, they nevertheless provide hints into the nuanced way courts approach sexual harassment cases.

\section{Case 1: Meritor v. Vinson}

Meritor v. Vinson (1986) is the first of the five cases presented here in this essay; actually, this is the first case in which the Supreme Court formidably elaborated sexual harassment as a violation of the Civil Rights Act. That way, the verdict given on June 19, 1986, is of landmark importance. In fact, this was the first sexual harassment case before the Supreme Court (Bull, 1993).

Associate Justice William H. Rehnquist, generally known to be a conservative judge, proclaimed that sexual harassment that is sufficient to create an intimidating work environment violates civil rights enshrined in the constitution. The judge, however, added that the bars for discrimination and sexual harassment were not the same. Emotional or psychological damage would amount to discrimination but not sexual harassment. Mechelle Vinson, the victim, was told she needed to establish evidence of intent of the employer to protect the harassers. Unfortunately, this created a huge exception for establishing sexual abuse.

To provide some more background to this case: Vinson, an African American woman of 19 years joined as a teller trainee at Meritor Savings Bank. Sidney Taylor was the manager, under whose supervision Vinson had to work. One day, Taylor took Vinson for dinner and told her the rules of the game to continue to work at the bank, which included offering him sex when he wanted it, watch pornographic materials with him, fondle his private parts, among other things. After four years of suffering the abuse, Vinson took sick leave and Taylor 
ISSN (online) - 2520-6311; ISSN (print) - 2520-6761

used this as an opportunity to fire her. As the case crawled slowly from lower courts to the Supreme Court, she had to do several odd jobs including selling newspapers to survive. The Trial Court, the Court of Appeals, or even the Supreme Court did not give her transcripts of the judgement.

It is not easy to decipher why the role of the employer in race discrimination or economic discrimination is easier to establish than in sexual harassment - other than find refuge in the ideological orientations of the judges. At one point in time, four judges in the panel declined to sign and four signed on it. Finally, the swing vote from Justice Sandra Day, the ninth judge, also a female, actually the first woman judge on the Supreme Court, came in favor of the judgement (Yuracko, 2019).

Robinson, Kirk, \& Stephens (1987) were some of the first authors who weighed on the broader implications of the Meritor v. Vinson case. Despite the popular media highlighting how progressive the decision was, the hidden aspect of it was employer liability. After this case, there has been a nationwide trend of businesses, big and small, investing heavily in coming up with virtuous sounding anti-harassment policies. In fact, protecting the boss(es) of the company from allegations and lawsuits became one of the most important functions of the human resource management department.

One way of looking at it, strict liability is too much unrealistic of an expectation; say, why should an employer be responsible if a supervisor harassed a subordinate outside of their work hours, during a party? The question is whether the employer anticipated this (e.g. based on previous criminal histories of the supervisor) or whether the employer used the best practices available to minimize the occurrence of the unwanted situation. Another way of looking at this is that, in the absence of strict liability for the companies, what we now have is an endless array of training programs and workshops; these have not been able to contain harassment or bring the guilty to the books. It must be reckoned that some State level legislations did come up later as a way to mitigate the damage done by the Supreme court. Regardless, the aftershocks of this case decision made more than 30 years ago still continue even today in our workplaces.

\section{Case 2: Faragher v. City of Boca Raton}

Faragher v. City of Boca Raton, 524 U.S. 775 (1998) relates to how the law views sexual harassment of supervisory employees upon their subordinates. It helped to clarify the court's views on what makes a hostile work environment. The verdict also gave an example of a situation in which the Title VII of the Civil Rights Act of 1964 could be invoked as part of a sexual harassment case (Faragher, 2004).

The complaint behind this case was brought to light when, in 1992, Beth Faragher brought to the notice of the City of Bocca Raton that Bill Terry and David Silverman, her supervisors, made her hard to work as a result of their constant sexually tinted advances toward her which included touching parts of her body considered very private. They offered her rewards if she would oblige to their desires; also, they threatened her with punishments for not obliging to their desires. In addition, these two supervisors explicitly and implicitly expressed numerous times their perception that women are inferior to men on various grounds. Faragher's accounts were corroborated by other lifeguards.

The verdict stressed that "an employer is vicariously liable for actionable discrimination caused by a supervisor but subject to an affirmative defense looking to the reasonableness of the employer's conduct as well as that of a plaintiff victim" (Faragher v. Boca Raton, 1998). While the court did agree that the supervisors were motivated by their personal, selfish, needs and not that of the organization, it nevertheless put partial blame on Faragher for not bringing this up early enough. It also protected the City from consequences by observing that there existed very little means for the employer to anticipate harassment would have happened.

What may be glean from this is that an employer is less likely to be punished if it:

(a) built mechanisms to prevent possible harassment scenarios, including training for both supervisors and subordinates;

(b) developed procedures and protocols that would make it easy for the victim to report abuses, including veiled ones;

(c) the employee, despite the existence of the above two opportunities, did not take advantage of them.

The above benefits will cease to exist for the employer, however, if the victim is tangibly demoted or terminated by the management and if this action could be proven to be linked to the complaint. Employers should make extra investments in providing training for supervisors on what is (un)lawful about sexual 
harassments - the ignorance of supervisors about prevailing laws, even when it is not willful, is something the courts would consider while determining if punitive damages are to be charged to the company.

\section{Case 3: Burlington Industries v. Ellerth}

This is another 1998 case that came up to the Supreme Court wherein the court had to determine what kinds of supervisory employee misconducts would make liable for sexual harassments. Just like Faragher v. Boca Raton (1998), this case too highlighted the importance for employers to follow best practices to avert possible sexual harassment situations.

Kimberly Ellerth, a female employee at Burlington Industries, alleged that her male supervisor, the vice president of sales, sexually harassed her. This included offensive remarks and unwelcome propositions. Also included were threats to deny tangible job benefits for not doing sexual favors. Her attorneys brought the case up under the umbrella of the violation of Title VII of the Civil Rights Act of 1964. A specific issue related to this case that the Supreme Court had to answer was the operational definition of "quid pro quo sexual harassment" (Scalia, 1997).

The 7-2 majority ruling including the following:

"Under Title VII, an employee who refuses the unwelcome and threatening sexual advances of a supervisor, yet suffers no adverse, tangible job consequences, may recover against the employer without showing the employer is negligent or otherwise at fault for the supervisor's actions, but the employer may interpose an affirmative defense" (Burlington Industries, Inc. v. Ellerth, 1998: 7).

Even though the final ruling was in her favor, the judges particularly scrutinized whether the agency relationship was used to take the action against the victim.

The judgement reiterates the prior verdicts in that if no action with a tangible consequence is taken, that favors the employer. Also, the existence of a workable sexual harassment policy will help the employer ward off some of the consequences. However, in this specific case, it is doubtful if the policy was 'workable': say, as per the policy, Ellerth would have been required to report the harassment to her supervisor, who himself is the harasser. Also, the court did not clarify the extent of overlap between an agent and an employer that is needed to establish the employer was at fault. This means, the agency standards to determine liabilities for the employer remained open to future interpretations (Fair, 1999).

\section{Case 4: Gebser et al. v. Lago Vista Independent School District}

Alida Star Gebser, a Lago Vista Independent School District a ninth-grade student, had a secret sexual affair with Frank Waldrop, one of her teachers. Waldrop engaged Gebser in sexual relations for approximately half a year, but never within the school premises. However, they were finally caught in the act and the teacher was arrested and then fired from his job. Gebser also never mentioned the affair to the school officials. In this case, the issue before the court was whether or when a school district can be held liable for damages for a student's sexual harassment by one of the teachers in the district, under Title IX of the Education Amendments of 1972.

Gebser's family sued the School District for damages, quoting excerpts from Title IX provisions:

"no person in the United States shall, on the basis of sex, be excluded from participation in, be denied the benefits of, or be subjected to discrimination under any education program or activity receiving Federal financial assistance".

The plaintiffs claimed compensatory and punitive damages from the school district and Waldrop. The lawsuit moved from the federal district court through the Fifth Circuit Court of Appeals to the US Supreme Court; all the courts ruled in a manner favorable to the school district. The Supreme Court refused to invoke the principle of common law which holds an employer responsible for the faulty performance of an agent. The court rather held that in order for an aggrieved party to recover sexual harassment damages under the amendments, two minimum criteria must be met. First, the party must demonstrate that the illegal activity was reported to a school district official with the power to enforce corrective measures. Second, it must be shown that the educational institution intentionally failed to respond appropriately although it was aware of the prohibited behavior. Since Lago Vista never knew of the existence of the illicit relationship, it could not act in a more forthcoming way. Lago Vista was therefore not responsible for damages caused by sexual harassment. 
ISSN (online) - 2520-6311; ISSN (print) - 2520-6761

Gebser told the Supreme Court that it took time for her to recognize that Waldrop's conduct was inappropriate and that even after recognizing this, she did not know how to react. This is likely true for children who are passing through a difficult phase of mental and emotional maturity. To me, it was surprising that the court did not weigh insufficiently the fact that Lago Vista had no official sexual harassment reporting procedure, nor did it follow federally mandated anti-harassment policy. The Supreme Court's determination that children deserve less protection than adults from sexual harassment is concerning.

The parents of two other students had protested in October 1992 about the remarks Waldrop made in class and this too was not reported to the school district's Title IX officer. If this happened, potentially more inquiries would have taken place. Also, the court did not follow in this case the precedent set in Franklin v. Gwinnett County Public Schools (1992) for the reason that this case had a different scope, according to the learned judges. In the light of these, Fay (1998) observed that it would not be the final word on school liability for teacher-to-student sexual harassment.

\section{Case 5: Davis v. Monroe County Board of Education}

Sexual harassments in our elementary and middle schools are more common than we think, observe Chaves (2000). So, how well are our children protected from peer harassment at schools? On May 24, 1999, the US Supreme Court in a 5-4 tight judgement held that school districts could be penalized under title IX for damages for failing to stop student-on-student sexual harassment. The court used the phrase "deliberately indifferent" to describe the attitude of the school. In popular parlance, this would sound more like a "boys will be boys" attitude (McClure, 2001). The court added that, for applying this kind of a judgement, the act of the school district should be such that "it interferes with the victim's education". This pathbreaking judgement was about Davis v. Monroe County Board of Education (Hughes, 1999).

Aurelia Davis, on behalf of her fifth-grade daughter LaShonda, sued the Monroe County Board of Education arguing that school officials failed to prevent another student (a classmate, identified as G.F) from sexually harassing Lashonda. During 1992-93, over a span of six months. G.F. reportedly harassed and assaulted her sexually, the lawsuit says. She and her mother informed of these to the class teacher and the school Principal, several times. The requests for safety and security for Aurelia were not fulfilled and no disciplinary measure was taken against the perpetrating child. Even a simple change in classroom seating arrangement was not made until after three months of complaining. The plaintiff sought injunctive relief and financial compensation from both the school district and the individually named school officials.

Both the district and the appellate courts sided with the school district; the Supreme Court granted the victim certiorari. The court took the majority view that there is an implied private right to education under Title IX and that private damage actions may be initiated against schools that deliberately neglect circumstantial cues or do not erect barriers to unlawful sexual conduct. There was an added stipulation, anticipating future litigations in similar situations. The court held that the harassment should be "serious enough to have the systemic effect of denying the victim equal access to an education program or activity". The term "systemic effect' would mean repeated occurrences of an event, a head in the sands approach by the school officials, and the absence of institutional processes in the schools to counteract harassment.

\section{Implications for Universities}

More frequent than the typical supervisor-subordinate relationship issues that we see in business settings (where both parties are employees), university environments are unique in that most harassment cases involve faculty-student relationships. A common scenario is one involving female students and male faculty members, although sexual harassment of women professors by male students are not entirely uncommon (Grauerholz, 1989). In this backdrop, sexual harassment in the academic institutional context may be defined as "the use of authority to emphasize the sexuality or sexual identity of a student in a manner which prevents or impairs the student's full enjoyment of educational benefits, climate, or opportunities" (Till, 1980: 7).

The U.S. Equal Employment Opportunity Commission (EEOC) has the following definition of sexual harassment:

"Submission to such conduct is made either explicitly or implicitly a term or condition of an individual's employment, submission to or rejection of such conduct by an individual is used as the basis for employment decisions affecting such individuals, or; such conduct has the purpose or effect of unreasonably interfering with an individual's work performance or creating an intimidating, hostile, or offensive working environment" (as cited in Connolly Jr, Connolly, \& Feinstein, 2018: 4). 
Courts tend to use the above definition in most contemporary workplace harassment cases, even those in educational settings (Allen, 2016). It is easier to apply it in cases involving a faculty member and their supervisor. Yet, since students are not employees, the above definition needs to undergo additional interpretative processes before it could be applied to academic environments involving faculty-student misconducts. It may also be worthwhile for legislatures and the judiciary to look into what the extant scholarly research reveals about how students perceive harassment. For instance, Loredo, Reid, \& Deaux (1995) found that high school students defined sexual harassment in terms of the behavior itself, the target's reaction to the behavior, the perpetrator's intentions, and the relationship that existed between the two people.

Several US universities have laid out clear and actionable procedures to address sexual harassment. For instance, Cornell University's Division of Human Resources integrates efforts by various other constituencies in the university which include the Department of Inclusion and Workforce Diversity, Workforce Policy and Labor Relations, Title IX Office, and Organizational Development and Talent Management. The university also provides safe and easy ways for victims to submit their complaints. The university website lists the following mechanisms to address sexual harassment (See Figure 2).

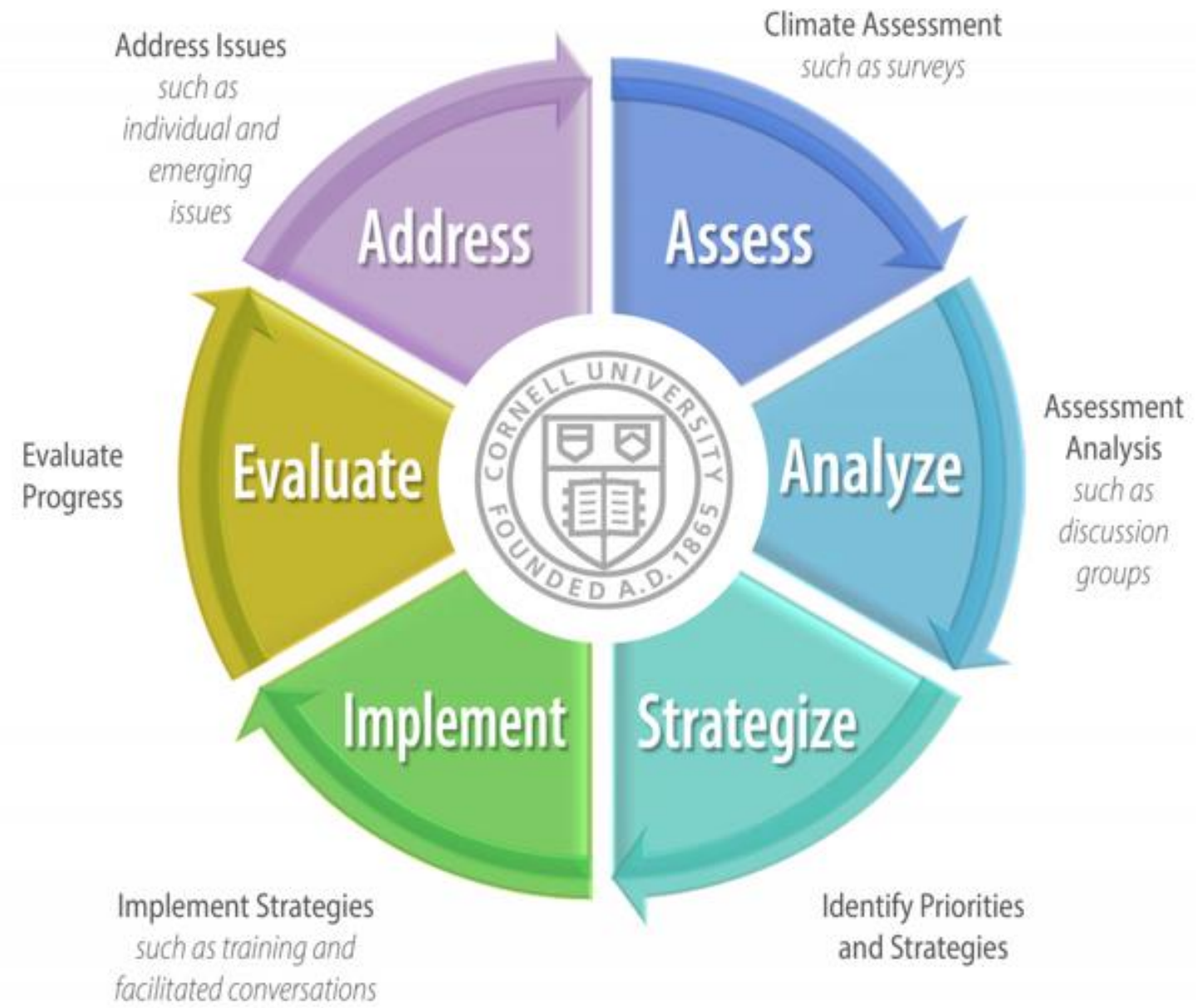

Source: Cornell University

Figure 2. HR resources addressing sexual harassment

In the popular media (that largely shapes public opinions), the students involved are portrayed as naïve and unthinking whereas the faculty involved are projected as the Wolf in the Little Red Riding Hood story. This characterization has now been embedded deeply in our collective psyches and it, in a curious process, makes both the students and the faculty to live up to it (Shurden, 2017). Sexual aspects of faculty-student relationships also trigger a heavy flow of emotions and this is often a key impediment in opening discussing it to find lasting solutions.

In the Faragher V. City of Boca Raton case, Beth Ann Faragher wrote a personal account of the agony she had to go through. The monitory award that the Supreme Court had to consider was $\$ 1-$ just one dollar (Faragher, 2004). In a strange yet understandable way, this must have helped Faragher in fending off public criticism that she was motivated by money. This is the same agony that our more contemporary victims need to face from the critical eyes of the society that tend to find faults with the victims of harassment claims. 
ISSN (online) - 2520-6311; ISSN (print) - 2520-6761

Another major criticism related to these pioneering court decisions is that it constrains plaintiffs in harassment cases to focus on what courts consider as key evidences, even when hurt feelings and pain come from elsewhere. In this vein, Green (2018) wonders whether Sexual Harassment law was a historic blunder. Looking at the bigger picture, the personal advances accounts that the courts insisted in the Meritor v. Vinson case led to a defocusing upon anything other than individualized wrongdoers and their beleaguered victims. Other kinds of harassment are so much better tied to the issue of broader inequality in our workplaces.

For higher education managers, the court verdicts in the harassment cases we discussed provide a great deal of succor. As discussed elsewhere in this paper, what they need to ensure for "affirmative defense" is that they did everything possible at their disposal in preventing it or put up their best efforts in assisting the victim if harassment actually happened. This includes considerate human-centric architectural designs of buildings and meeting areas, development of a coherent and comprehensive policy as well as the dissemination of it in a manner that is digestive for everyone, and a workable enforcement mechanism of rules related to harassment. One of the upcoming best practices that courts may look favorably is whether institutions frequently assess their sexual harassment climate employing some scientifically established measurement criteria (Goldberg \& Ahmed, 2019).

Based on the five pioneering cases we discussed here, courts habitually expect that complaints need to first be filed formally within the organization, through proper channels: this is something that tends to be misused by employers (Medina, 2017). In their eagerness to support insider interests, the complaints are shared with the perpetrators (who also often happen to be supervisors of the victims); this would lead to a situation of the perpetrators taking advantage of the information and building false narratives. In academic institutions when a team of "friendly" colleagues looks into the sexual harassment allegations against a professor, this could, unfortunately, become the case. It is important for universities to isolate supervisors from the harassment reporting chain if the supervisors are identified as perpetrators (Meyers, 2015). Also, at the choice of the victim, there should be informal ways of airing grievances (Fusilier \& Penrod, 2015). Otherwise, since the requirements for claiming affirmative defense are fluid and up to individual judges and since the primary concern of most employers is to avoid vicarious liability rather than to bring justice to the victims, there is a lot of room for malpractice by the employers.

A deterrent to the above is the incentive for universities to protect their reputation. Other confounding factors such as the tenure status and the prestige of the individual (e.g. a professor with multimillion-dollar grant funds or a Nobel laureate faculty) also come into play while decisions are made. However, how all this act out depends on the moral compass of the decision-makers, organizational cultures, and an assessment of what is more likely to guard reputations. Say, in the event that decision-makers think reputation is protected by a coverup, typically before public outcry reaches a flashing point, they might be tempted to side with the perpetrators of harassment. However, universities also recognize that protests act as negative advertisements that would make it difficult for them to attract students (Witze, 2017).

\section{Conclusion}

In this paper, we discussed five US Supreme Court lawsuits that would later have consequences for how sexual harassment complaints are dealt within our educational institutions. Particularly, the last two were directly related to happenings in our schools. In the implications section, we specifically elaborated on the implications of the court decisions upon these cases for student-student, subordinate-supervisor, and studentteacher relationships in the US universities, with special mention on institutional liability. While these cases did not succeed in providing a saturated sample for generating a cohesive or comprehensive set of guidelines, they nevertheless guided future court judgements and also organizational policies with respect to managing sexual harassment. Based on a holistic look at all the five cases discussed, one would think that the Supreme Court has not yet given a final word on whether and when institutional liability is transferred to the employer from the perpetrator.

The shifts in viewpoints amongst the judges that became more and more evident as these cases moved up in the litigation process also point to the fact that a straightforward and inter-subjectively agreeable interpretation of the law is not possible. Factors such as the presence of quid pro quo attempt to notify the institution of continuing harassment, availability of institutional processes to address harassment, etc., factor into the judgements. This author finds that the Supreme Court verdict in Gebser et al. v. Lago Vista Independent School District was the most troubling and regressive one for me. The court seemed to have 
weighed too much on the absence of timely reporting and underplayed the fact that the victim was an underaged student who did not know everything.

Added to the above is the fact that our $21^{\text {st }}$ century workplaces, especially universities, are very different from what we have seen in the past. For example, technologies, particularly information and communication technologies, offer new methods and venues for sexual misadventures. The cases discussed here do not address or make full sense in dealing with technology medicated stacking and harassment.

Changes in cultural norms, particularly those in gendered sexual norms in even non-gendered work, obfuscate things even more. A "grand theory" of sexual harassment has become an impossible target to achieve, also because of the fact that our workplaces have become more multicultural, multiracial, and multiethnic. Cultural norms related to acceptable conduct vary significantly across these groups and judges cannot turn a blind eye to prejudices and preconceptions stemming from the cultural foundations of the victims and the perpetrators.

The pronouncements in the Supreme Court that we discussed in this paper, Title IX, and related laws provide a good starting point; yet, higher education institutions need to come up with other alternative ways of dealing with sexual harassment, observes Witze (2018). In this spirit, Chen \& Sambur (1999) asked the following radical question: are consensual relationship agreements a solution to sexual harassment in the workplace (when the parties involved are not minors)? Employers allow their employees to take up additional jobs or get into external consulting assignments as long as they declare it and submit a conflict of interest statement. Why not the same be said about sexual relationships? These authors did provide some solid arguments for and against this.

Organizations need not be labeled as places that do not have any heart for the human feelings of the employees working in them. Michell, Szorenyi, Falkner, \& Szabo (2017) advocates for "broadening participation not border protection", when it comes to relationships in the workplace. The question has always been on conducting relationships without coercion of any kind. The grounds for a university to establish to the court in "good faith" that a relationship between a professor and a student was out of innocent human cravings are limited, even in the presence of a mechanism like consensual relationship agreement. Hence, the practical solution to this problem to this day is imperfect, ugly, and at least in some cases blind to genuine human feelings.

\section{References}

1. Allen, D. (2016). Barking and biting: the equal opportunity commission as an enforcement agency. Federal Law Review, 44(2), 311-335. https://doi.org/10.1177/0067205x1604400206.

2. Bull, C. A. (1993). The Implications of Admitting Evidence of a Sexual Harassment Plaintiff's Speech and Dress in the Aftermath of Meritor Savings Bank v. Vinson. UCLA L. Rev., 41, 117.

3. Burlington Industries, Inc. v. Ellerth, 524 U.S. 742, 118 S. Ct. 2257, 141 L. Ed. 2d 633 (1998).

4. Chen, A. J., \& Sambur, J. A. (1999). Are consensual relationship agreements a solution to sexual harassment in the workplace. Hofstra Lab. \& Emp. LJ, 17(1), 165-189.

5. Chaves, L. (2000). Responding to public school peer sexual harassment in the face of Davis v. Monroe County Board of Education. BYU Educ. \& LJ, 287. Available at: https://scholarlycommons.law.hofstra.edu/cgi/viewcontent.cgi?article=1502\&context=hlelj.

6. Cohen, C. F. (1987). Implications of "Meritor Savings Bank, FSB v. Vinson et al.". Labor Law Journal, $38(4), 243$.

7. Connolly Jr, W. B., Connolly, M. J., \& Feinstein, J. (2018). A practical guide to equal employment opportunity. Law Journal Press. https://doi.org/10.7591/9780801454592-020.

8. Fair, C. (1999). Burlington Industries, Inc. v. Ellerth and Faragher v. City of Boca Raton: A step in the wrong direction. BU Pub. Int. LJ, 9, 409-415.

9. Faragher v. Boca Raton, 524 U.S. 775, 118 S. Ct. 2275, 141 L. Ed. 2 d 662 (1998).

10.Faragher, B. A. (2004). Faragher v. City of Boca Raton: A Personal Account of a Sexual Discrimination Plaintiff. Hofstra Lab. \& Emp. LJ, 22, 417.

11.Fay, J. C. (1998). Gebser v. Lago Vista Independent School District: Is it Really the Final Word on School Liability for Teacher-to-Student Sexual Harassment. Conn. L. Rev., 31, 1485.

12.Fitzgerald, L. F., \& Cortina, L. M. (2018). Sexual harassment in work organizations: A view from the 21st century. APA Handbook of the Psychology of Women: Perspectives on Women's Private and Public Lives, 2(1), 215-234. https://doi.org/10.1037/0000060-012. 
Business Ethics and Leadership, Volume 3, Issue 4, 2019

ISSN (online) - 2520-6311; ISSN (print) - 2520-6761

13.Fusilier, M., \& Penrod, C. (2015). University employee sexual harassment policies. Employee Responsibilities and Rights Journal, 27(1), 47-60. https://doi.org/10.1007/s10672-014-9255-0.

14.Goldberg, C., \& Ahmad, A. (2019). Improving the measurement of sexual harassment climate. Industrial and Organizational Psychology, 12(1), 64-67. https://doi.org/10.1017/iop.2019.10.

15.Grauerholz, E. (1989). Sexual harassment of women professors by students: Exploring the dynamics of power, authority, and gender in a university setting. Sex Roles, 21(11-12), 789-801. https://doi.org/10.1007/bf00289809.

16. Green, T. K. (2018). Was Sexual Harassment Law a Mistake - The Stories We Tell. Yale LJF, 128, 152-153. Available at: https://www.yalelawjournal.org/forum/was-sexual-harassment-law-mistake.

17.Hughes, W. (1999). School liability for student sexual harassment. American Secondary Education, 28(2), 23-25. Available at: https://www.jstor.org/stable/41064376?seq=1.

18.Loredo, C., Reid, A., \& Deaux, K. (1995). Judgments and definitions of sexual harassment by high school students. Sex Roles, 32(1-2), 29-45. https://doi.org/10.1007/BF01544756.

19.McClure, T. (2001). Boys will be boys: Peer sexual harassment in schools and the implications of Davis v. Monroe County Board of Education. Hastings Women's LJ, 12, 95. Available at: https://repository.uchastings.edu/cgi/viewcontent.cgi?article $=1265 \&$ context=hwlj.

20.Medina, K. F. (2017). Workplace Discrimination and the Inefficiency of the Ellerth/Faragher Defense. Brigham Young University Prelaw Review, 31(1), 8-11. Available at: https://scholarsarchive.byu.edu/byuplr/vol31/iss1/8.

21.Meritor Savings Bank, FSB v. Vinson, 477 U.S. 57, 106 S. Ct. 2399, 91 L. Ed. 2d 49 (1986).

22.Meyers, S. D. (2015). Who's the Boss: The Definition of a Supervisor in Workplace Harassment Under Vance v. Ball State University. Saint Louis University Law Journal, 59(3), 19-27. Available at: https://scholarship.law.slu.edu/lj/vol59/iss3/19.

23.Michell, D., Szorenyi, A., Falkner, K., \& Szabo, C. (2017). Broadening participation not border protection: how universities can support women in computer science. Journal of Higher Education Policy and Management, 39(4), 406-422. https://doi.org/10.1080/1360080x.2017.1330821.

24.Robinson, R. K., Kirk, D. J., \& Stephens, E. C. (1987). Hostile Environment: A Review of the Implications of "Meritor Savings Bank v. Vinson". Labor Law Journal, 38(3), 179.

25. Scalia, E. (1997). Strange career of quid pro quo sexual harassment, the. Harv. JL \& Pub. Pol'y, 21, 307-326.

26.Shurden, S. (2017). The legal aspect of faculty/student relationships in higher education. Global Journal of Business Disciplines, 1(2), 76.

27.Till, F. J. (1980). Sexual Harassment: A Report on the Sexual Harassment of Students. Washington, DC: National Advisory Council on Women's educational Programs.

28.Witze, A. (2017). Nine researchers sue University of Rochester over sexual-harassment allegations. Nature, 552(7684), 35-48. https://doi.org/10.1038/d41586-017-08235-z.

29.Witze, A. (2018). Sexual harassment is rife in the sciences, finds landmark US study. Nature, 558(7710), 352-354. https://doi.org/10.1038/d41586-018-05404-6.

30.Yuracko, K. A. (2019). Sexual harassment law: an evolution in theory, scope and impact. In Research Handbook on Feminist Jurisprudence. Edward Elgar Publishing. https://doi.org/10.4337/9781786439697.00026. 